\title{
Ecological Assessment Of Performance Of Tree Species Used In Rehabilitating Degraded Areas Of Turkana County, Kenya
}

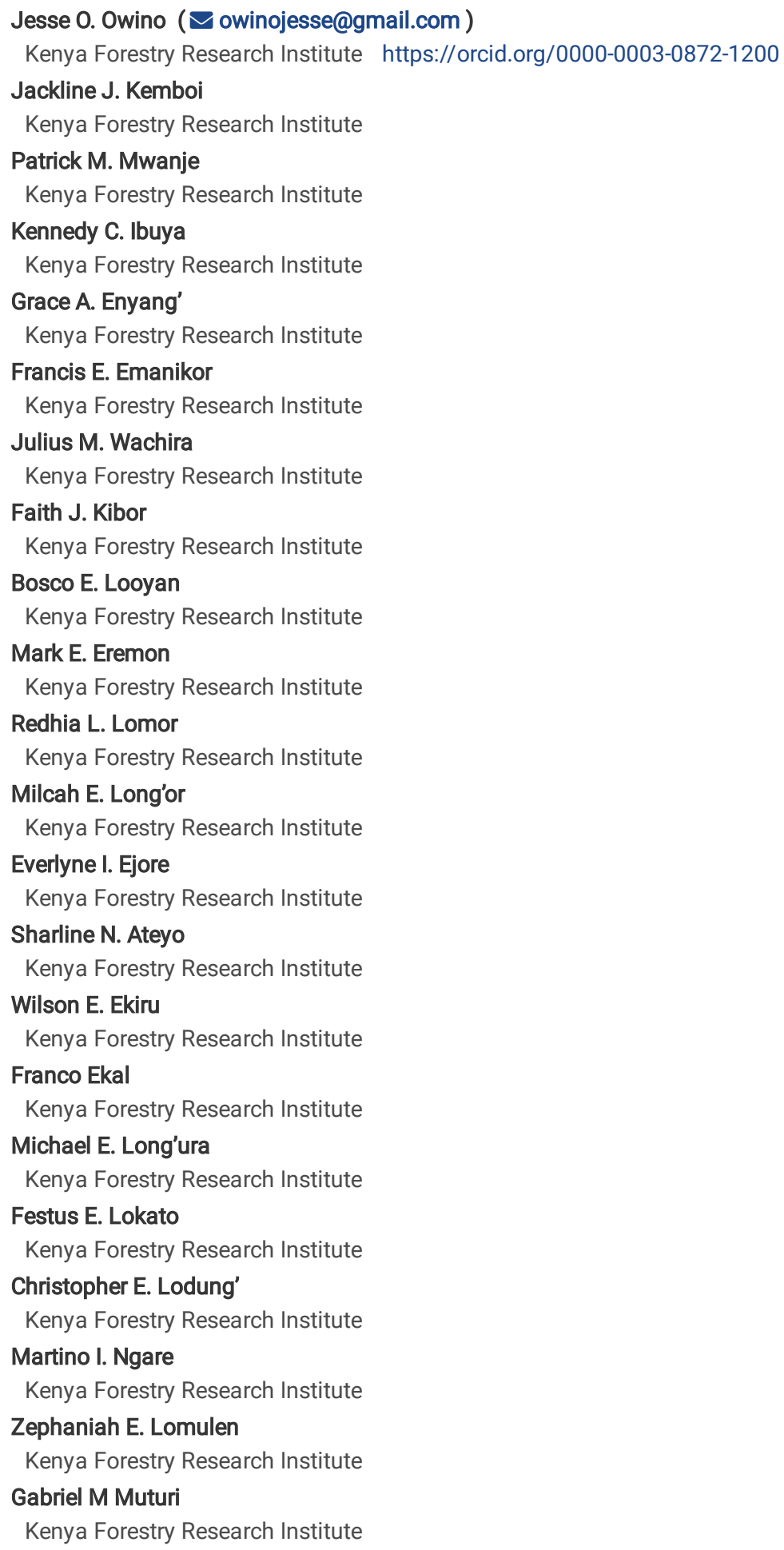

\section{Research article}

Keywords: Ecological performance, native tree species, rehabilitation, degraded areas, Arid and semi-arid areas, Turkana County 
DOI: https://doi.org/10.21203/rs.2.14308/v1

License: (a) (i) This work is licensed under a Creative Commons Attribution 4.0 International License. Read Full License 


\section{Abstract}

Background Dry regions are facing environmental challenges which have resulted in biodiversity and soil fertility loss. It is highly recognized that trees contribute a range of ecosystem services in urban environments. Rehabilitation using indigenous tree species in Kenya faces challenges as the country lacks guidelines on species site matching. The main objective of this study was to assess the ecological performance of rehabilitation efforts in two arid and semi-arid (ASAL) sites with varying number of tree species but not abundance in each of the sites. The study further determines the efficacy of rehabilitation by varying the number of species in degraded ASAL areas. This study employed ecological study technique using height, diameter at breast height (DBH), Soil pH and compared the performance of the tree species in the field against performance of similar species at their early growth stages in the nursery. Results The study results showed significantly higher soil pH in the nursery $(p<0.05)$ than in both the degraded ASAL field sites. Similarly, the mean tree heights were significantly higher $(p<0.05)$ in site with higher species diversity than site with lower species diversity. There was no significant difference $(p>0.05)$ in the species DBH in the two sites. Conclusions Other than soil amendments for fertility improvement to increase rtrees perfomance, there is need to rehabilitate degraded areas with higher tree species diversity to achieve a resilient heterogeneous ecosystem. This study has shown how adding economic valuation of tree species would lead to awarenenss and importance on key native species.

\section{Introduction}

Dry lands are important ecosystems in the world which occupies about $41 \%$ of the earth land surface and support about 2 billion inhabitants (FAO, 2016). Drylands include terrestrial regions, majorly characterized by water scarcity which limit production of crops, wood, forage and provision of other ecosystem services(Millennium Ecosystem Assessment, 2005a). The report by the Millenium Ecosystem Assessment (2005b), indicates that over 90\% of people living in the dry land are from developing countries and mainly depend on forest and non-wood forest products to meet their basic needs for food , shelter, wood, medicine and forage for livestock. In sub-Saharan Africa, dry land forest play a significant role in conservation of biodiversity and harbouring of unique and endemic species that are well adapted to harsh climatic condition while providing essential ecosystem services(FAO, 2010). Africa's drylands constitute about $65 \%$ of the total land mass and a major source of forage for ruminants(Zerga et al., 2018). However, most of these dry land areas are caught in spiral of desertification, degradation and drought (DLDD) as well as deforestation and land fragmentation (FAO, 2010). Thus threatening food security, ecosystem integrity and quality of life of both dryland and non-dryland communities (Millenium Ecosystem Assessment, 2005; Reynolds et al., 2007).

Land degradation and deforestation has well been documented as the major threat to human well-being and environment due to the resulting loss in biodiversity, soil erosion and significant contribution to greenhouse emission(Jama \& Zeila, 2005; Kiptoo \& Mirzabaev, 2014; Yirdaw et al., 2017; Zerga et al., 2018). According to Millenium Ecosystem Assessment (2005a), 10-20\% of dryland s are already degraded and if uncheck, the desertification and degradation of ecosystem services in drylands will threaten the improvement of human wellbeing in future. Studies conducted by Kiptoo and Mirzabaev (2014) shows that land degradation cause huge economic loss which affect an estimate of 1.5 billion people globally. Land degradation in the rangelands of Kenya is not an exception. The government of Kenya recognizes land degradation as a serious threat to the country's economy, which cause an annual economic loss of USD 390Million or 3\% of country's GDP (GoK, 2016a). Land degradation also threatens the livelihoods of millions of rural people who depend solely on land ecosystem goods and services (Mulinge et al., 2015). The most critical driver of land degradation is poor land management which include destruction of natural forests for timber, charcoal production, expansion of agricultural land, overgrazing, mining and infrastructure projects (MENR, 2015; GoK, 2016a), thus leading to increased runoff, flash flooding, soil erosion, reduced infiltration and siltation of rivers and dams.

Kenya's forest cover and woodlands are increasingly under pressure from the ever growing human population and man of these woodlands are shrinking due to human-induced deforestation(Gichora et al., 2009). The forest cover in Kenya has changed from 3,708,000 hectares to 3,467,000 hectares from 1990 to 2010(MENR, 2015). As a result of deforestation, the country is losing approximately 12000 hectares of forests annually(Stiebert et al., 2012). Based on the land degradation assessment report by (GoK, 2016a), national forest cover was estimated at $6.99 \%$ by 2014 against the target forest cover of $10 \%$ (MENR, 2015), while $2.2 \%$ of the land area of Kenya is bare. This report further indicates that $71.9 \%$ of the Kenya's land is at a higher risk of degradation due to poor vegetation cover.

The Arid and Semi-Arid Lands (ASALs) of Kenya which occupies about $80 \%$ of the total land mass are characterized by low rainfall, poor soil structure and highly susceptible to land degradation(GoK, 2016b). Because of the increasing human induce pressure on these fragile ecosystems compounded by the slow recovery rate, decline productivity, loss of biodiversity, loss of vegetation cover and increasing rate of soil erosion is evident in this environments(Mganga et al., 2010). Turkana County being an ASAL area has a natural forest cover of about 4.06\%(Turkana County Government, 2015). According to the Turkana County integrated Development Plan of 2018 , about $50 \%$ of the county is highly degraded due to overgrazing leaving vegetation cover without enough time to regenerate, deforestation for charcoal production, infestation of invasive weeds and unsustainable irrigation practices resulting to salinization. Climate change has also exacerbated desertification and forest degradation, with adverse impacts on the economic benefits and livelihoods derived from the forestry sector, as well as biodiversity and other environmental services(Stiebert et al., 2012). Currently, land degradation continues to threaten food security, water quality and quantity, grazing areas and climate change adaptation and mitigation strategies, thus leading to huge economic losses and destitution of pastoral communities in the county (CIDP, 2018).

Significant efforts have been made by the Kenyan Government in the recent years to reverse the impacts of degradation through tree planting in the ASALs(Mengich et al., 2013). The Kenya Vision 2030, Constitution of Kenya 2010, National Climate Change Response Strategy and land policy among other policies provide guidelines for mitigation of land degradation and protection of forests. The Kenya vision 2030 long term development blueprint

Page $3 / 10$ 
commits the country to mitigate unintended adverse land degradation and calls for rehabilitation of degraded forest areas and sustainable management of dryland forests(GoK, 2007). The forest conservation and management act (FCMA, 2016) and Vision 2030 provide synergies for increasing forest cover to $10 \%$ through tree planting. Despite presence of the existing polices and measures for combating degradation, the process has severely been constrained by a narrow species selection, use of exotic trees that are not well adopted to drylands and inadequate information to guide selection of suitable tree species(Mengich et al., 2013). Due to water scarcity and high soil moisture deficit experienced in this harsh environments, rehabilitation is more challenging and slow (Mganga et al., 2010; Yirdaw, Tigabu and Monge, 2017). However, successful rehabilitation has been achieved in low rainfall areas. For instance, the use of enclosures have been effective in restoring plant species diversity, composition, biomass and vegetation structure of herbaceous and woody components in the drylands of Ethiopia (Yayneshet, Eik and Moe, 2009) and Kenya (Mureithi, Verdoodt and Ranst, 2010; Wairore, 2015). Experiments conducted by (Owino, Kemboi and Muturi, 2018) shows the importance of using native species that are well adopted to the local climate and water harvesting infrastructures for successful establishment of tree stands in semi-arid areas. The use of techniques such as pitting, contour furrows and trenches are important in creation of micro and macro-catchment which reduces runoff thus ensures long period availability of water to the plant thereby improving establishment (Mganga et al., 2010). Correspondingly, planting of appropriate tree species in respective localities has also been known to lead to successful rehabilitation of degraded sites(Mengich et al., 2013). Prediction of field performances of tree species based on the early growth characteristics at the nurseries is also possible in identifying tree species that will not survive or will perform poorly under field condition(Mattsson, 1996).

This study therefore sought to assess the ecological performance of rehabilitation efforts in two ASAL degraded sites with varying number of tree species with similar abundance in each of the sites, establish the variability of species in the two sites, determine performance of species in early growth stages in the nursery against those in the field, and compare by volume the species in the two sites.

\section{Materials And Methods}

\section{Study site}

The study was conducted within three sites; Ekalees (3.08465N 35.63903E) one of the site is $10 \mathrm{~km}$ off Lodwar-Kitale road (Owino J., 2018 ) and 0.12 ha. The plot was fenced with scarcely populated tree species. The second plot was Nadapal (3.08188 N $35.53378 \mathrm{E})$ which is 4 ha and it is located in Loima sub-county. The plot was fenced with higher density vegetation cover and monitoring is subsequently undertaken. The final plot was KEFRI nursery $\left(3.112550^{\circ} \mathrm{N}, 35.599170^{\circ} \mathrm{E}\right)$ which is 0.2 ha and it served as a control experiment. Different measurements in the nursery can be used for identification of seedlings that are not likely to survive or grow in the field (Mattsson, 1996).

Figure 1. Map Showing Locations of Nadapal (3.08188 N 35.53378 E), Ekalees (3.08465N 35.63903E) and Nursery site (3.112550, $\left.35.599170^{\circ} \mathrm{E}\right)$

KEFRI nursery is under good management and condition which allow the growth of various tree species. All the plots are fenced to protect the species from human disturbance and being eaten by browsers. The soil pH differed in all the sites. The most common soil type found in all the sites is sand soil but in the nursery there is a mixture of sand, forest soil and manure in the ratio of 5:3:2.

\section{Materials and methods}

The instruments used were height pole of $500 \mathrm{~cm}$ length, wooden meter rule of $100 \mathrm{~cm}$ length, Vernier calipers (accuracy $0.02 \mathrm{~mm}$ ) and pH tester. Once a tree was selected, the following information was recorded: Diameter of the stems at breast height (DBH) above $1 \mathrm{~m}$, relative height of trees, Soil pH, root color diameter of seedlings and tress below $1 \mathrm{~m}$. Vertical heights were estimated using height pole of $500 \mathrm{~cm}$ length and a wooden meter rule of $100 \mathrm{~cm}$ length. DBH and RCD were measured using Vernier calipers (accuracy $0.02 \mathrm{~mm}$ ), Soil pH was measured using 4 in $1 \mathrm{pH}$ tester and Portable Demetra soil $\mathrm{pH}$ meter (range 3.5 to $8 \mathrm{pH}$ ) placed $8 \mathrm{~cm}$ slanted into the soil.

\section{Data collection}

To assess the impact of afforestation which were established in Ekalees (approximately 4 years) and Nadapal (approximately 1 year). The tree measurements taken were; tree height, soil ph., crown cover diameter, diameter at breast height or root collar diameter. Every tree species in every site was counted and measured. Systematic sub-sampling method was used in nursery plot whereby 10 seedlings were selected counted and measured.

Further variables were derived from the tree measurements using the equation below

(i) Volume/tree $\left(\mathrm{m}^{3}\right)=3.14 * \mathrm{DBH}^{2} / 4 * \mathrm{Ht} * \mathrm{f}$

where $\mathrm{DBH}=$ mean Root collar diameter/diameter at breast height per tree, $\mathrm{Ht}$ is mean height per tree and $\mathrm{f}$ is the form factor which is eucalypts=0.6; pine $=0.45$; cypress $=0.41$; and grevillea all indigenous species $=0.3$

(ii) Total volume $\left(\mathrm{m}^{3}\right)=$ Volume/tree $\left(\mathrm{m}^{3}\right) \star$ average number of trees per hectare*area $(\mathrm{Ha})$.

(iii) Approximate value per tree= Total volume $\left(\mathrm{m}^{3}\right)^{*}$ Value $(\mathrm{kshs})$ per vol $\left(\mathrm{m}^{3}\right)$ (Republic of Kenya, 2016).

The data was tabulated using Microsoft excel, and analyzed to determine means of the various variables using R-stat. A 2-way ANOVA was performed to find significant through comparing blocks and sites. Further, a post-hoc TukeyHSD was done to know the variables that were significantly different.

Page $4 / 10$ 


\section{Results}

Table 1 illustrates the species diversity, soil pH and performance in the three sites (Nursery, Ekalees and Nadapal). The study showed a higher species diversity in Ekalees (9 spp) though lower species population (68) than in Nadapal which had lower species diversity (5 spp) and higher species populations (106). The nursery had the highest diversity (13 spp) of species at early growth stages (Table 1).

The Nursery also recorded a significantly higher cumulative soil $\mathrm{pH}(6.4 \pm 0.03, \mathrm{p}<0.05)$ around all the tree seedlings than Ekalees and Nadapal $(6.3 \pm$ $0.05,6.2 \pm 0.04$ ) respectively (Table 1$)$.

The mean tree heights were significantly higher $(\mathrm{p}<0.05)$ in Ekalees $(352.4 \pm 14.90 \mathrm{~cm})$, a site with higher species diversity than in Nadapal $(230.9 \pm 11.18$ $\mathrm{cm})$, a site with lower species diversity. However, there was no significant difference $(\mathrm{p}>0.05)$ in the species DBH in the two sites and planting times. Cordia sinensis was recorded as the tallest tree species with a mean height of $413.23 \pm 12.77 \mathrm{~cm}$ (Table 1). The nursery (Control) recorded the lowest mean heights of all the tree species as compared to Ekalees and Nadapal. The Species heights in the 'Field' block were all significantly different except for Aloe turkanensis (Table 1).

The mean Root Collar Diameter (RCD)/(Diameter at Breast Height (DBH) for Ekalees was not significantly different ( $p>0.05)$ when Ekalees was compared to Nadapal (Table 1). The species with the largest DBH was Zizyphus mauritania with DBH of $9.53 \mathrm{~cm}$.

This study found that growth curves showed the Balanites aegyptiaca and Ziziphus mauritania having the fastest growth as per the Height vs RCD/DBH correlation coefficients (Figure 2).

The individual tree volume had the largest tree as Ziziphus mauritania $\left(12833 \mathrm{~m}^{3}\right)$. In terms of average volume per hectare, the largest tree species were Cordia sinensis $\left(61210 \mathrm{~m}^{3} / \mathrm{ha}\right)$ with Grewia tenax being the smallest $\left(102 \mathrm{~m}^{3} / \mathrm{ha}\right)$ (Table 1$)$.

The results on tree valuation showed that the highest valued tree species was Cordia sinensis with a value of kshs $280,831,591$ and the lowest valued species was Grewia tenax at kshs 467,242 for the field species (Table 1).

Table 1. Species performance showing of the mean heights, RCD/DBH, age of trees per ha, volume of trees, total volume and value of trees at the Nursery, Nadapal and Ekalees sites in Turkana County, Kenya. The last 3 rows show mean totals for each site. ( \pm Standard Error and small letters in superscript denote significant difference $(p<0.05))$ 


\begin{tabular}{|c|c|c|c|c|c|c|c|c|c|c|c|}
\hline Site & Block & Species & $\underset{(n)}{\text { Sample }}$ & SOIL pH & HEIGHT (cm) & $\begin{array}{l}\mathrm{RCD} / \mathrm{DBH} \\
(\mathrm{cm})\end{array}$ & $\begin{array}{l}\text { Area } \\
(\mathrm{Ha})\end{array}$ & $\begin{array}{l}\text { Avg } \\
\text { trees/(Ha) }\end{array}$ & $\begin{array}{l}\text { Vol_tree } \\
\left(\mathrm{m}^{3}\right)\end{array}$ & $\begin{array}{l}\text { total Vol } \\
\left(\mathrm{m}^{3}\right)\end{array}$ & Value (Kshs) \\
\hline Nursery & Control & $\begin{array}{l}\text { Aloe } \\
\text { turkanensis }\end{array}$ & 10 & $6.5 \pm 0.09$ & $24.7 \pm 3.96$ & $2.8 \pm 0.61$ & 0.20 & 50 & 45.80 & 458.00 & 2101292.97 \\
\hline Nursery & Control & $\begin{array}{l}\text { Azadirachta } \\
\text { indica }\end{array}$ & 10 & $6.7 \pm 0.08$ & $19.4 \pm 1.96$ & $0.3 \pm 0.02$ & 0.20 & 50 & 0.43 & 4.25 & 19509.20 \\
\hline Nursery & Control & $\begin{array}{l}\text { Balanites } \\
\text { aegyptica }\end{array}$ & 10 & $6.4 \pm 0.15$ & $31.3 \pm 2.13$ & $0.3 \pm 0.01$ & 0.20 & 50 & 0.60 & 5.98 & 27434.25 \\
\hline Nursery & Control & $\begin{array}{l}\text { Casuarina } \\
\text { equisetifolia }\end{array}$ & 8 & $6.4 \pm 0.13$ & $88.9 \pm 9.08$ & $5.9 \pm 0.34$ & 0.20 & 40 & 722.72 & 5781.75 & 12997378.58 \\
\hline Nursery & Control & $\begin{array}{l}\text { Cordia } \\
\text { sinensis }\end{array}$ & 10 & $6.5 \pm 0.14$ & $59.9 \pm 4.47$ & $0.5 \pm 0.02$ & 0.20 & 50 & 4.04 & 40.38 & 252918.27 \\
\hline Nursery & Control & $\begin{array}{l}\text { Dobera } \\
\text { glabra }\end{array}$ & 10 & $6.2 \pm 0.10$ & $27.8 \pm 2.09$ & $0.7 \pm 0.065$ & 0.20 & 50 & 3.63 & 36.34 & 166713.84 \\
\hline Nursery & Control & $\begin{array}{l}\text { Grevillea } \\
\text { robusta }\end{array}$ & 10 & $6.7 \pm 0.13$ & $7.3 \pm 0.73$ & $0.2 \pm 0.03$ & 0.20 & 50 & 0.09 & 0.87 & 3987.56 \\
\hline Nursery & Control & $\begin{array}{l}\text { Grewia } \\
\text { tenax }\end{array}$ & 10 & $6.3 \pm 0.09$ & $17.2 \pm 1.62$ & $0.2 \pm 0.01$ & 0.20 & 50 & 0.23 & 2.33 & 10673.35 \\
\hline Nursery & Control & $\begin{array}{l}\text { Melia } \\
\text { volkensii }\end{array}$ & 8 & $6.8 \pm 0.07$ & $31.9 \pm 2.93$ & $1 \pm 0.04$ & 0.20 & 40 & 6.86 & 54.91 & 251940.16 \\
\hline Nursery & Control & $\begin{array}{l}\text { Parkinsonia } \\
\text { aculeata }\end{array}$ & 10 & $6.4 \pm 0.11$ & $91.2 \pm 10.48$ & $0.6 \pm 0.07$ & 0.20 & 50 & 8.12 & 81.22 & 372618.27 \\
\hline Nursery & Control & $\begin{array}{l}\text { Salvadora } \\
\text { persica }\end{array}$ & 10 & $6.4 \pm 0.07$ & $21.9 \pm 2.14$ & $0.4 \pm 0.05$ & 0.20 & 50 & 0.67 & 6.68 & 30666.45 \\
\hline Nursery & Control & $\begin{array}{l}\text { Senna } \\
\text { siamea }\end{array}$ & 10 & $6.4 \pm 0.09$ & $73.2 \pm 9.60$ & $0.5 \pm 0.05$ & 0.20 & 50 & 4.57 & 45.69 & 209625.02 \\
\hline Nursery & Control & $\begin{array}{l}\text { Zizyphus } \\
\text { mauritania }\end{array}$ & 10 & $6.3 \pm 0.10$ & $33.5 \pm 2.41$ & $0.4 \pm 0.04$ & 0.20 & 50 & 1.14 & 11.39 & 52235.65 \\
\hline Ekalees & Field & $\begin{array}{l}\text { Aloe } \\
\text { turkanensis }\end{array}$ & 2 & $5.2 \pm 0.80$ & $40.3 \pm 3.75$ & $4.2 \pm 0.30$ & 0.12 & 17 & 167.21 & 334.41 & 1534294.69 \\
\hline Ekalees & Field & $\begin{array}{l}\text { Azadirachta } \\
\text { indica }\end{array}$ & 10 & $6.3 \pm 0.13$ & $375.3 \pm 26.6$ & $3.5 \pm 0.45$ & 0.12 & 83 & 1060.45 & 10604.51 & 48653482.85 \\
\hline Ekalees & Field & $\begin{array}{l}\text { Balanites } \\
\text { aegyptica }\end{array}$ & 3 & $6.4 \pm 0.12$ & $334 \pm 8.41$ & $7.3 \pm 0.24$ & 0.12 & 25 & 4153.44 & 12460.32 & 57167942.21 \\
\hline Nadapal & Field & $\begin{array}{l}\text { Casuarina } \\
\text { equisetifolia }\end{array}$ & 19 & $6.1 \pm 0.05$ & $265.3 \pm 23.59$ & $3.8 \pm 0.37$ & 4.00 & 5 & 883.89 & 16793.93 & 37752756.71 \\
\hline Ekalees & Field & $\begin{array}{l}\text { Cordia } \\
\text { sinensis }\end{array}$ & 38 & $6.3 \pm 0.06$ & $413.23 \pm 12.77$ & $4.1 \pm 0.16$ & 0.12 & 317 & 1610.79 & 61210.02 & 280831590.65 \\
\hline Ekalees & Field & $\begin{array}{l}\text { Dobera } \\
\text { glabra }\end{array}$ & 3 & $6.6 \pm 0.12$ & $98.7 \pm 14.84$ & $3.2 \pm 0.19$ & 0.12 & 25 & 237.94 & 713.81 & 3274960.02 \\
\hline Nadapal & Field & $\begin{array}{l}\text { Grevillea } \\
\text { robusta }\end{array}$ & 28 & $6.4 \pm 0.06$ & $121.7 \pm 6.16$ & $2.6 \pm 0.17$ & 4.00 & 7 & 199.34 & 5581.46 & 25607747.91 \\
\hline Ekalees & Field & $\begin{array}{l}\text { Grewia } \\
\text { tenax }\end{array}$ & 4 & $6.5 \pm 0.26$ & $227.1 \pm 38.86$ & $0.7 \pm 0.17$ & 0.12 & 33 & 25.46 & 101.84 & 467241.94 \\
\hline Nadapal & Field & $\begin{array}{l}\text { Melia } \\
\text { volkensii }\end{array}$ & 37 & $6.1 \pm 0.07$ & $227.5 \pm 16.99$ & $4.1 \pm 0.30$ & 4.00 & 9 & 893.68 & 33066.20 & 151707734.08 \\
\hline Ekalees & Field & $\begin{array}{l}\text { Parkinsonia } \\
\text { aculeata }\end{array}$ & 2 & $6.6 \pm 0.20$ & $389.3 \pm 42.25$ & $6.9 \pm 0.35$ & 0.12 & 17 & 4301.31 & 8602.62 & 39468814.37 \\
\hline Ekalees & Field & $\begin{array}{l}\text { Salvadora } \\
\text { persica }\end{array}$ & 4 & $6.2 \pm 0.22$ & $252 \pm 11.63$ & $2.1 \pm 0.27$ & 0.12 & 33 & 271.15 & 1084.59 & 4976077.09 \\
\hline Nadapal & Field & $\begin{array}{l}\text { Senna } \\
\text { siamea }\end{array}$ & 21 & $6.4 \pm 0.06$ & $333.7 \pm 13.01$ & $2.3 \pm 0.15$ & 4.00 & 5 & 403.81 & 8480.03 & 38906399.55 \\
\hline Ekalees & Field & $\begin{array}{l}\text { Zizyphus } \\
\text { mauritania }\end{array}$ & 2 & $6.3 \pm 0.30$ & $217 \pm 91.00$ & $2.3 \pm 0.63$ & 0.12 & 17 & 276.25 & 552.49 & 2534836.57 \\
\hline Nadapal & Field & $\begin{array}{l}\text { Zizyphus } \\
\text { mauritania }\end{array}$ & 1 & $6.4 \pm 0.00$ & $600 \pm 0.00$ & $9.53 \pm 0.00$ & 4.00 & 0 & 12832.99 & 12832.99 & 58877772.66 \\
\hline Nursery & Control & Total spp & 126 & $6.4 \pm 0.03^{a}$ & $40.0 \pm 2.74^{\mathrm{a}}$ & $1.0 \pm 0.13^{\mathrm{a}}$ & 0.2 & 48 & 61 & 502 & 22396156.72 \\
\hline Ekalees & Field & Total spp & 68 & $6.3 \pm 0.05^{b}$ & $352.4 \pm 14.90^{\mathrm{b}}$ & $3.8 \pm 0.19^{b}$ & 0.12 & 63 & 1345 & 10629 & 473943747.2 \\
\hline Nadapal & Field & Total spp & 106 & $6.2 \pm 0.04^{b}$ & $230.9 \pm 11.18^{\mathrm{c}}$ & $3.3 \pm .16^{\mathrm{b}}$ & 4 & 5 & 3043 & 15351 & 684467024 \\
\hline
\end{tabular}

Figure 2. Height and RCD/DBH curves for each trees species at the Nursery, Nadapal and Ekalees sites in the study in Turkana County, Kenya.

\section{Discussion}

Species diversity increases ecosystem complexity and functionality overtime(Aerts and Honnay, 2011). Restoration of degraded areas using different tree species alter the physical and chemical characteristics of the soil through decomposition of litter fall, thus providing suitable abiotic conditions that allows recolonization of other species. The species diversity differences in the two sites enables the ecological analysis by comparison of the sites. The site with a higher tree species diversity had more liter fall and understory vegetation compared to the site with low species diversity. The meta analysis of the results conquers with studies conducted by Aerts and Honnay (2011) which shows that ecosystem functioning increases with species number due to increased processes of decomposition of organic matter, nutrient and water cycling and carbon fixation. Studies conducted by Yirdaw et al., (2017) also shows rehabilitation success through active restoration approaches such as introduction of different tree species and using enclosures to assist in natural regeneration on native trees. 
The soil pH in the tree sites were fairly different. The Nursery $\mathrm{pH}$ is closer to neutral and this is due to the nursery soil medium being a mixture of sand, manure and forest soil in the ratio of 5:2:3 respectively. The $\mathrm{pH}$ changes in the field is basically due to the sites having very little nutrients with low soil organic matter. This is evidenced by the low soil $\mathrm{pH}$ for both field sites.

The field site with higher species diversity (Ekalees) was found to have cumulatively higher heights of the tree species than the site with lower species diversity (Nadapal) despite the DBH for the two sites not being significantly different. The higher heights in Ekalees compared to Nadapal resulted from the strong intraspecific competition between the tree species. Studies conducted by Saha et al., (2014) shows that trees planted with close spacing triggers high intraspecific competition because the trees compete intensely for light, thus allocating more of its resources to height growth rather than diameter growth.

Native species were found to have better adaptation to environmental conditions and better individual growth forms than non-native species. This was also observed in Owino et al., (2018) from one of the field sites where native trees had a faster growth rate and showed more resilience to harsh climatic conditions compared to the non-native tree species. The difference in the volume of trees per hectare was brought about by the changes in tree $\mathrm{DBH}$ in relationship with heights.

In terms of average volume per hectare, the largest tree species was Cordia sinensis $\left(61210 \mathrm{~m}^{3} / \mathrm{ha}\right)$ with Grewia tenax being the smallest (102 $\left.\mathrm{m}^{3} / \mathrm{ha}\right)$ (Table 1). The high inter-species competition among the Cordia species stimulated their growth characteristics thus, a higher total volume of species per hectare. Further experiments by Lövenstein et al., (1991) shows that trees planted at close spacing tend to have less volume per tree compared to trees planted at open spacing but have larger volume per unit area.

Valuation of trees is a fundamental component in promoting investment in tree management. According to McPherson (2007), less investment in tree management results in deterioration of tree health and functionality in an ecosystem. Valuation of tree species is also influenced by the age and size of the tree species, such that the high higher the volume of the tree, the more value attached to it. Cordia sinensis which had a higher volume per unit area was highly valued compared to Grewia which had the smallest volume per unit area. Similarly, due to its fast growth and resilience to harsh climatic condition, Cordia sinensis showed strong cha

The tree valuation showed that the highest valued tree species was Cordia sinensis with a value of kshs $280,831,591$ and the lowest valued species was Grewia tenax at kshs 467,242 for the field species (Table 1). Valuation of trees is directly proportional to the tree volume thus the highest valuation of Cordia sinensis. Cordia sinensis proved to be a valuable species in the dryland because of its fast growth and resilience to the climatic condition.

\section{Conclusion And Recommendation}

A better understanding of variations in plant performance in drylands and valuation can better improve attitudes and practices for sustainable rehabilitation of degraded landscapes. Valuation of trees provides a better understanding of the socio-economic benefits for subsistence and commercial uses of tree such as fodder, fuel or fruits as well as environmental services in pastoral systems. Tree density and diversity influences growth pattern of individual tree species. The use of native tree species for rehabilitation of degraded sites at closer spacing showed better growth characteristics than trees planted at wider spacings. Higher species diversity provided a better ecological niche for plants competition thus stimulating terminal growth and improvement of soil through litter fall. Tree species planted at close spacing tend to produce significantly lower biomass than trees planted at open spacing. Higher planting densities results in lower biomass production per tree but higher biomass production per unit areas. The performance of tree species at the nursery and field conditions showed huge variations simply because of the changes in the biophysical factors and management practices. Based on the study results, better performance of trees at the nursery is a proof of good management practices. For better performance of trees at field condition spaces, there is need for soil amendments for fertility improvement and moisture retention. Higher species diversity is also critical in rehabilitation of degraded ASAL areas.

\section{Declarations}

Ethics approval and consent to participate- Not Applicable as data was on research sites with plant materails in non destructive sampling complying with Kenya Forestry Research Institute's giedlines and policies.

Consent to publish- The authors consent to the publication of this paper

Availability of data and materials- The data is available YOUR TEMPORARY REVIEW LINK:https://datadryad.org/review? doi=doi:10.5061/dryad.d1b6g9m (for journal access prior to manuscript acceptance only. Include with your submitted manuscript but NOT in the final proofs) YOUR DRYAD DOI: doi:10.5061/dryad.d1b6g9m

Competing interests- The authors have no competing interests

Funding- The did not receive specific funding and resources came from Government of Kenya-Kenya Forestry Research Institute- Financial year 2018/2019 funding.

\section{Authors' Contributions}


Jesse O. Owino ${ }^{1, *}$, ,Planning, design, analyzing data, writing paper

Jackline J. Kemboi ${ }^{1,2}$ - design and analysing

Patrick Mwenje ${ }^{1}$, - analyzing and writing paper

Kennedy C. Ibuya ${ }^{1}$, Grace A. Enyang ${ }^{1}$, Francis E. Emanikor ${ }^{1}$, Julius M. Wachira ${ }^{1}$, Faith J. Kibor ${ }^{3}$, Bosco E. Looyan ${ }^{3}$, Mark E. Eremon ${ }^{4}$, Redhia L. Lomor ${ }^{1}$, Milcah E. Long'or ${ }^{1}$, Everlyne I. Ejore ${ }^{6}$, Sharline N. Ateyo ${ }^{6}$, Wilson E. Ekiru ${ }^{6}$, Franco Ekal ${ }^{7}$, Michael E. Long'ura ${ }^{8}$, Festus E. Lokato ${ }^{8}$, Christopher E. Lodung ${ }^{10}$, Martino I. Ngare ${ }^{10}$, Zephaniah E. Lomulen ${ }^{5}$, - Data collection for individual species

Gabriel Muturi ${ }^{11}$ - design and proof reeading

\section{Acknowledgments}

The authors acknowledge the logistical support received from KEFRI Lodwar sub-Centre administration: Mr. Sammy Eramram, Mr. Ekiru Fredrick, Mr. Peter Matinyi and Ann Elizabeth Kilui. We are also grateful to Mr. Richard Ekitela and Mr. Nicholas Lorot for managing Lodwar KEFRI nursery which acted as a control block for study. Lots of thanks to Turkana County Government for establishing and managing the Ekalees site which was one of the field for the research study. We are sincerely grateful to Mr. Josphat Marang'ach and Ms Margaret Natir for granting us access to Nadapal site for data collection. Further appreciation goes to Mr. Dennis Eregae, Lodwar KEFRI driver and Mr. Joseph Lobei, Lodwar KFS driver for taking us to and fro the sites for the many times we went for data collection.

\section{References}

Aerts, R. and Honnay, O. (2011) 'Forest restoration, biodiversity and ecosystem functioning', BMC Ecology. BioMed Central Ltd, 11(1), p. 29. doi: $10.1186 / 1472-6785-11-29$.

Assessment, M. E. (2005a) Ecosystems and Human Well-Being: Desertification Synthesis. Washington, DC.

Assessment, M. E. (2005b) Ecosystems and Human Well Being: Synthesis. Island Press, Washington, DC.

CIDP (2018) Turkana County Integrated Development Plan (CIDP II)-2018-2022.

FAO (2010) 'Guidelines on sustainable forest management in drylands of sub-Saharan Africa', Arid Zone Forest and Forestry Working Paper No 1, p. 47. Available at: http://www.fao.org/docrep/012/i1628e/i1628e00.pdf.

FAO (2016) Trees, forests and land use in drylands. ROME. Available at: http://www.fao.org/3/a-i5905e.pdf.

FCMA (2016) 'Forest Conservation and Management Act', Kenya Gazette Supplement, 155(34), pp. 677-736. doi: 10.1007/s11947-009-0181-3.

Gichora, M. et al. (2009) 'Forests and woodlands'.

GoK (2007) Kenya Vision 2030 - A Globally Competitive and Prosperous Kenya. Nairobi, Kenya. doi: 10.1111/j.1464-410X.2005.05807.x.

GoK (2016a) Land Degradation Assessment in Kenya: Based on a Study of Land Degradation Assessment (LADA) with Remote Sensing and GIS, for Sustainable Land Management (SLM) in Kenya. Nairobi. Available at: http://www.environment.go.ke/wp-content/uploads/2018/08/LADA-LandDegradation-Assessment-in-Kenya-March-2016.pdf.

GoK (2016b) 'Policy and Institutional Frameworks for SLM in Kenya Overview of the: Policy, Legislative and Institutional Frameworks for Sustainable Land Management in the Public Sector in Kenya', NEPAD Planning and Coordination Agency, (February). Available at: http://www.environment.go.ke/wpcontent/uploads/2018/08/Overview-of-Policies-and-Institutional-frameworks-on-SLM-in-Kenya-Feb-2016.pdf.

Jama, B. and Zeila, A. (2005) 'Agroforestry in the drylands of eastern Africa: A call for action', ICRAF Working Paper - no. 1, pp. 1-38.

Kiptoo, K. O. and Mirzabaev, A. (2014) Economics of Land Degradation in Eastern Africa. 128.

Lövenstein, H. M., Berliner, P. R. and van Keulen, H. (1991) 'Runoff agroforestry in arid lands', Forest Ecology and Management, 45(1-4), pp. 59-70. doi: 10.1016/0378-1127(91)90206-B.

Mattsson, A. (1996) 'Predicting field performance using seedling quality assessment', pp. 1984-1985.

McPherson, E. G. (2007) 'Benefit-based tree valuation', Arboriculture and Urban Forestry, 33(1), pp. 1-11.

Mengich, E. K. et al. (2013) 'Composition and distribution of indigenous trees and shrubs as possible criteria for indicating adapted species in semi-arid rangelands', pp. 1-13. 
MENR (2015) 'Ministry of Environment and Natural Resources Information brief No . 2 WIDENING INFORMED STAKEHOLDER ENGAGEMENT IN REDD + The underlying causes and drivers of deforestation and forest', (2), pp. 6-9.

Mganga, K. Z. et al. (2010) 'The role of Moisture in the successful Rehabilitation of Denuded Patches of a Semi Arid Environment in Kenya', Journal of Environmental Science and Technology, 3(4), pp. 19-207.

Mulinge, W. et al. (2015) 'Economics of Land Degradation and Improvement in Kenya', in Economics of land degradation and improvement - $A$ global assessment for sustainable development, pp. 471-498. doi: 10.1007/978-3-319-19168-3.

Mureithi, S. M., Verdoodt, A. and Ranst, E. Van (2010) 'Effects and Implications of Enclosures for Rehabilitating Degraded Semi-arid Rangelands: Critical Lessons from Lake Baringo Basin, Kenya', in Land Degradation and Desertification: Assessment, Mitigation and Remediation. doi: 10.1007/978-90-4818657-0.

Owino, J., Kemboi, J. and Muturi, G. M. (2018) 'Rangeland Rehabilitation Using Micro-Catchments and Native Species in Turkana County, Kenya', in Chagala-Odera, E. et al. (eds) CONTRIBUTION OF FORESTRY RESEARCH TO SUSTAINABLE DEVELOPMENT Proceedings of 5 th KEFRI Scientific Conference at KEFRI Headquarters Muguga, pp. 496-506.

Republic of Kenya (2016) Kenya Gazette Supplement No. 16. doi: 10.1108/s1059-433720160000069011.

Reynolds, J. F. et al. (2007) 'Global Desertification: Building a Science for Dryland Development', Science, 316(5826), pp. 847 LP - 851. doi: $10.1126 /$ science. 1131634 .

Saha, S., Kuehne, C. and Bauhus, J. (2014) 'Intra- and interspecific competition differently influence growth and stem quality of young oaks (Quercus robur L. and Quercus petraea (Mattuschka) Liebl.)', Annals of Forest Science, 71(3), pp. 381-393. doi: 10.1007/s13595-013-0345-1.

Stiebert, S. et al. (2012) 'Kenya 's Climate Change Action Plan: Mitigation Chapter 4: Forestry', (August).

Turkana County Government (2015) Final Report Natural Resource Mapping and Context Analysis.

Wairore, N. J. (2015) 'Influence of Enclosure Management Systems on Rangeland Rehabilitation in Chepareria, West Pokot County, Kenya', (November), p. 103. doi: 10.13140/RG.2.1.1954.9522.

Yayneshet, T., Eik, L. O. and Moe, S. R. (2009) 'The effects of exclosures in restoring degraded semi-arid vegetation in communal grazing lands in northern Ethiopia', Journal of Arid Environments. Elsevier Ltd, 73(4-5), pp. 542-549. doi: 10.1016/j.jaridenv.2008.12.002.

Yirdaw, E., Tigabu, M. and Monge, A. (2017) 'Rehabilitation of degraded dryland ecosystems - review', Silva Fennica, 51(1), pp. 1-32. doi: 10.14214/sf.1673.

Zerga, B. et al. (2018) 'Rangeland Degradation and Rehabilitation Efforts in the Somali National Regional State, Eastern Ethiopia: A Review', International Journal of Innovative Research and Development, 7(5). doi: 10.24940/ijird/2018/v7/i5/may18026.

\section{Figures}




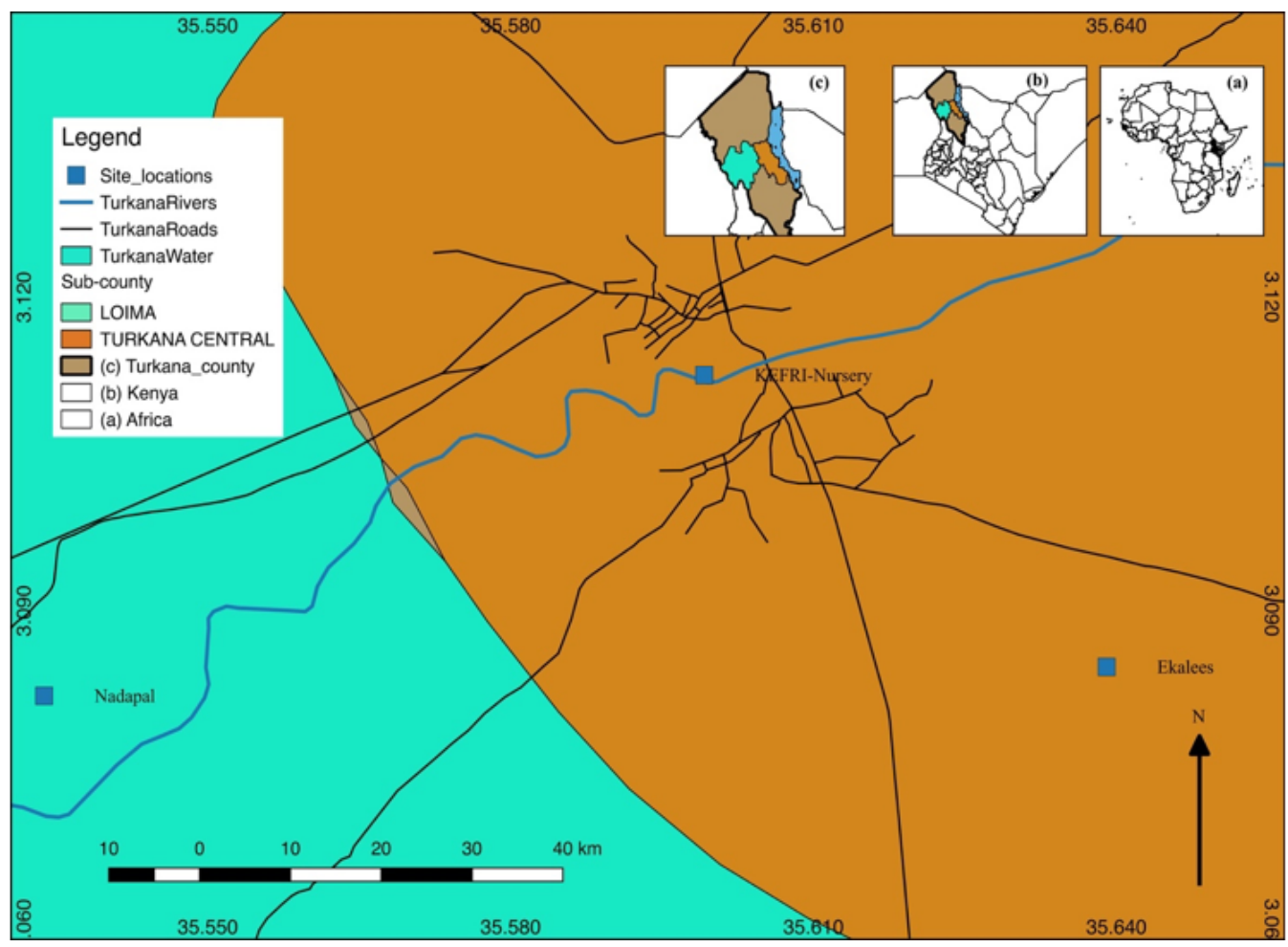

\section{Figure 1}

Map Showing Locations of Nadapal (3.08188 N 35.53378 E), Ekalees (3.08465N 35.63903E) and Nursery site (3.112550oN, 35.599170o E)

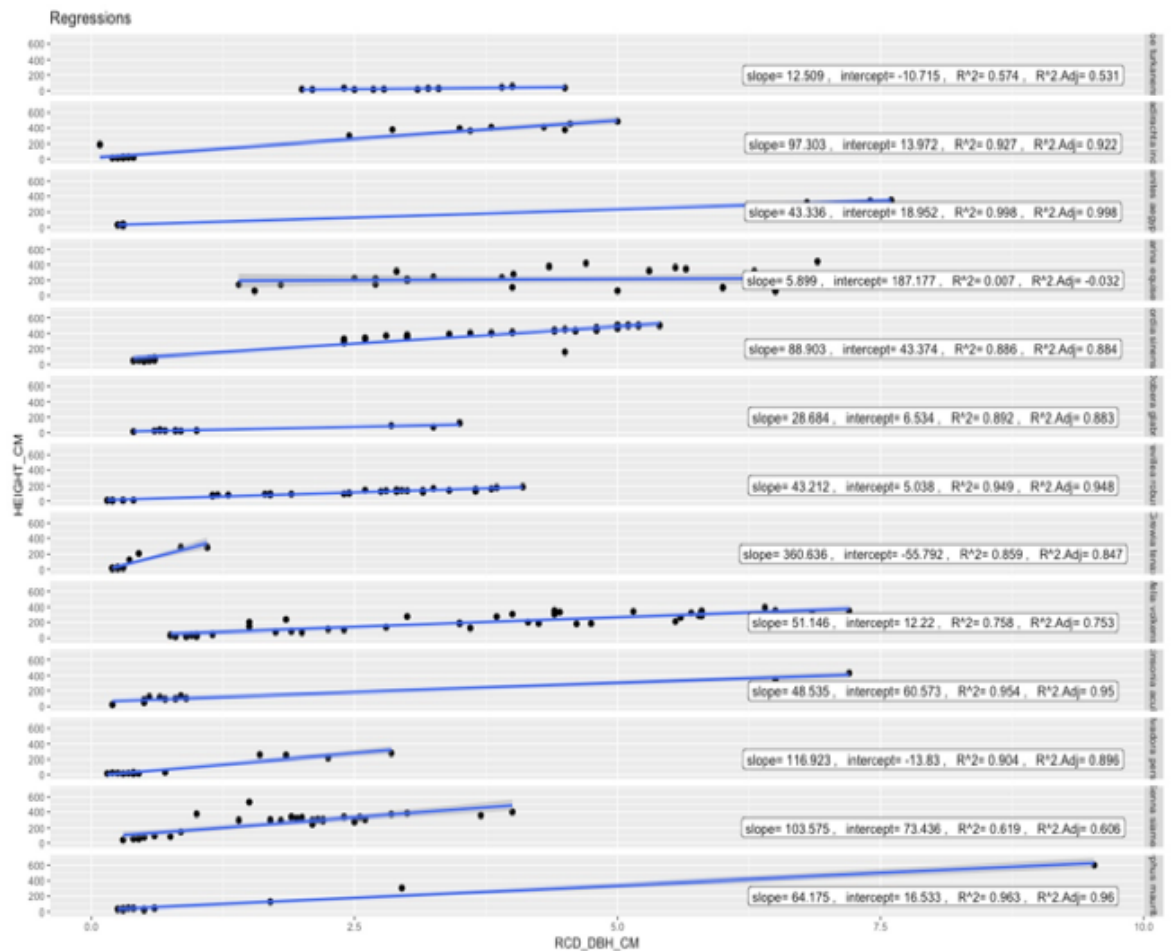

\section{Figure 2}

Height and RCD/DBH curves for each trees species at the Nursery, Nadapal and Ekalees sites in the study in Turkana County, Kenya. 